Intra-arterial infusion of alcohol produced a decrease in skin blood-flow, so that the vasodilator effect of oral alcohol is not a direct one.

Alcohol decreases muscle blood-flow.

I wish to express my thanks to Mr. William Brough for much technical assistance; also to Mr. John Hynd. Mr. P. Hammond and Mr. V. Scoon kindly undertook the alcohol estimations.

Postscript.-Since this paper was submitted for publication J. D. Fewings, M. J. D. Hanna, J. A. Walsh, and R. F. Whelan (Brit. F. Pharmacol. 1966, 27, 93) have recorded the results of a plethysmographic study of the effects of ethyl alcohol on the blood vessels of the hands and forearms of healthy subjects. Their observations are similar to those reported above for healthy upper limbs. However, they failed to detect any increase in blood-flow in the hand of one patient sympathectomized five years previously or in one patient with a brachial plexus avulsion, and thus inferred that alcohol vasodilatation was sympathetically mediated. In the present investigations all eight sympathectomized upper limbs showed vasodilatation -large in six of them-even shortly after operation, when the denervated hand was hot and flushed compared with the unoperated hand.

\section{REFERENCES}

Abramson, D. I., Zazeela, H., and Schkloven, N. (1941). Amer. Heart 7., $21,756$.

Conrad, M. C., and Green, H. D. (1964). Circulation, 29, 847.

Edwards, J. W. L. Jones, and Watson, D. C. (1952). Brit. med. F., 2, 808.

Gillespie, J. A. (1959). Lancet, 2, 995.

Whitney, R. J. (1949). F. P. Pysiol. (Lond.), 109, 5P.

\title{
Pyuria in Infancy, and the Role of Suprapubic Aspiration of Urine in Diagnosis of Infection of Urinary Tract
}

\author{
C. G. H. NEWMAN,* M.B., M.R.C.P., D.C.H. ; PAULINE O'NEILL, † B.M., B.CH. ; ANN PARKER, A.I.M.I.T
}

Brit.med.9., 1967, 2, 277-279

The many studies of infections of the urinary tract in infants and children show how far we are from knowing the natural history of this disease. Even in the absence of structural abnormalities of the urinary tract infections appear to be common. It is clear that progressive renal damage can occur with so few symptoms that the presenting signs may be due to hypertension (Loyd Still and Cottom, 1967) or uraemia. It is suggested that many of these infections originate in the first year of life, and particularly in the first month (Stansfeld, 1966). Radiological abnormalities may be detected in up to $50 \%$ of infants and children presenting with infection of the urinary tract (Smellie et al., 1964), and infection may be followed by scarring and impaired renal growth (Hodson and Wilson, 1965).

Positive diagnosis is fundamental to any study. It is unfortunate that most studies of urinary infection in infancy have rested upon the application of statistical probabilities to individual urinary findings. When, as with infants, a variable degree of specimen contamination is unavoidable, refinements in the techniques of cell and bacterial counting do not entirely eliminate diagnostic error. We feel that the uncertainties which surround the natural history of urinary infection in infancy will not be resolved until a method of obtaining uncontaminated infant urine is in general use. It was with this in mind that we applied to the study of the urine of newborn infants a method by which urine is aspirated from the bladder through the anterior abdominal wall. This technique, first described for infants by Pryles et al. (1959) and Pryles (1965), has already been used in adult surveys (Stamey et al., 1965; Beard et al., 1965), and in a study of premature infants by Nelson and Peters (1965). We here describe its application to a survey of urine findings in 162 healthy newborn infants. In a further small series we have assessed the value of suprapubic aspiration of urine in the diagnosis of infection of the urinary tract in infants and young children.

\section{Patients and Methods}

First Series.-Urine was collected from healthy neonates on about the sixth day. Only babies who were clinically well and were gaining weight satisfactorily were included. Clean specimens of urine were obtained with adhesive plastic bags, $\ddagger$ by the technique normally employed in our neonatal nurseries. Instructions are given that the infant shall be carefully cleansed before the bag is applied, and that watch shall be kept so that specimens can be collected and refrigerated as soon as possible after micturition. Cell and bacterlal counts were carried out by two of us (P. O'N. and A. P.) personally, using standard bacteriological techniques. Specimens were kept refrigerated and were cultured on the day of collection, except for three specimens which were refrigerated overnight. The technique of suprapubic aspiration is described in the Appendix.

Second Series.-This comprised infants and children seen in medical outpatient departments or in the wards. All had symptoms suggestive of infection of the urinary tract, but satisfactory urine specimens could not be obtained or had given ambiguous answers. Nineteen children have been investigated so far. Cultures, white cell counts, and colony counts were done by two of us (P. O'N. and A. P.), except in the case of a few specimens which were examined by clinical laboratory staff in the course of routine work.

\section{Results in First Series}

Clean-bag specimens were collected from 162 healthy newborn infants ( 99 male, 63 female).

Bacterial counts are shown in Fig. 1. The bacterial count exceeded $10^{5}$ organisms $/ \mathrm{ml}$. in 104 of the 162 infants. Most cultures were mixed, but about one-quarter of all specimens yielded a pure or predominant growth of one type of organism only.

Cell counts are shown in Fig. 2. The sex difference is even more pronounced than that found by James (1959) and by Lincoln and Winberg (1964). In our series 90 of the 99 bovs had white cell counts below 5/cu. inm., whereas 17 of the 63

* Children's Department, St. Thomas's Hospital, London S.E.1

† Lecturer in Bacteriology, Lambeth Hospital, London S.E.1.

¥ Chironseal, Great Ormond Street, Hospital pattern. 
girls had counts above $50 / \mathrm{cu}$. mm., and nine of these had more than $100 \mathrm{cells} / \mathrm{cu}$. mm.

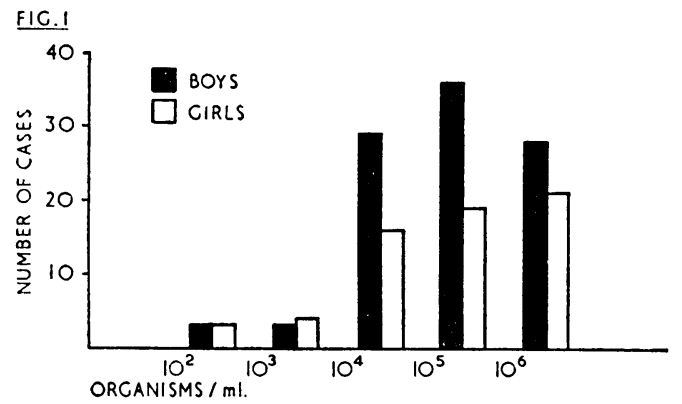

Fig. 1.-Distribution of bacterial counts in clean-bag apecimens of urine in 162 healthy newborn infants.

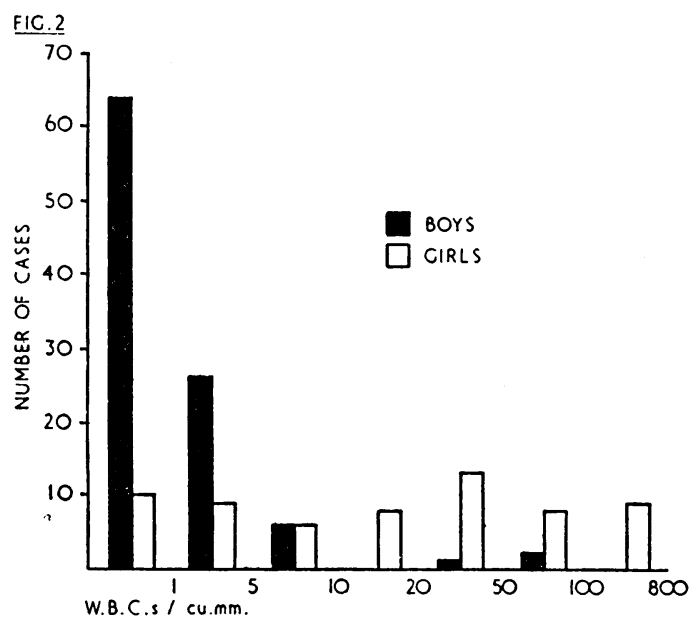

FIG. 2.-Distribution of white cell counts in clean-bag specimens of urine in 162 healthy newborn infants.

Follow-up of Infants with "Abnormal" Urinary Findings in Clean-bag Specimens. - We decided to follow up and, where possible, obtain bladder urine by suprapubic puncture from all infants having urinary white cell counts exceeding $20 / \mathrm{cu} . \mathrm{mm}$. There were 33 such children ( 30 girls, three boys), and further specimens (suprapubic, clean-bag, or both) were obtained as soon as possible from 27 of them. Twenty-two had suprapubic puncture, and the absence of infection was proved in all of

Comparison of Suprapubic and Clean-bag Urine Specimens from 22 Newborn Infants Found to Have More than $20 \mathrm{White}$ Cells $/ \mathrm{cu}$. mm. of Urine on the Fourth to Seventh Day of Life

\begin{tabular}{|c|c|c|c|c|c|c|}
\hline \multirow[t]{2}{*}{ Sex } & \multirow{2}{*}{$\begin{array}{l}\text { White Cell } \\
\text { Count On } \\
\text { First } \\
\text { Clean-Bag } \\
\text { Specimen (at } \\
\text { age 4-7 days) }\end{array}$} & \multicolumn{2}{|c|}{$\begin{array}{c}\text { Suprapubic } \\
\text { Aspiration } \\
\text { Specimen (S.P.A.) }\end{array}$} & \multicolumn{2}{|c|}{$\begin{array}{l}\text { Corresponding } \\
\text { Clean-bag } \\
\text { Specimen }\end{array}$} & \multirow{2}{*}{$\begin{array}{l}\text { Time Interval } \\
\text { Between } \\
\text { S.P.A. and } \\
\text { Corresponding } \\
\text { Clean-Bag } \\
\text { Specimen }\end{array}$} \\
\hline & & $\begin{array}{c}\text { Cells } \\
\text { cu. mm. }\end{array}$ & Orgs./ml. & $\begin{array}{l}\text { Cells } \\
\text { cu. } \mathrm{mm} .\end{array}$ & Orgs./ml. & \\
\hline $\begin{array}{l}\mathrm{M} \\
\mathbf{F}\end{array}$ & $\begin{array}{r}31 \\
24 \\
720\end{array}$ & $\begin{aligned} & 6 \\
&<<1 \\
&<1 \\
&<1 \\
&<1\end{aligned}$ & $\begin{array}{c}\text { Sterile } \\
\text { " } \\
\# \\
\#\end{array}$ & $\begin{array}{r}15 \\
14 \\
6 \\
<1 \\
222\end{array}$ & $\begin{array}{c}10^{5-6} \\
10^{5-6} \\
10^{5-6} \\
10^{3-4} \\
\text { Not }\end{array}$ & $\begin{array}{l}<2 \text { hours } \\
<2 \text { " } \\
<2 \text { ", } \\
<2 \text { ", } \\
48 \text { ", }\end{array}$ \\
\hline$\underset{F}{\mathbf{F}}$ & $\begin{array}{l}250 \\
213\end{array}$ & $\left\{\begin{array}{r}3 \\
6 \\
1 \\
\text { Not }\end{array}\right.$ & ", & $\begin{array}{l}32 \\
87 \\
34 \\
20\end{array}$ & $\begin{array}{l}\text { counted } \\
10^{4-5} \\
10^{6+} \\
10^{4-5} \\
10^{5-6}\end{array}$ & $\begin{array}{l}<2 \text { " } \\
<2 \text { ", } \\
<2 \text { ", } \\
1 \text { week }\end{array}$ \\
\hline $\begin{array}{l}\mathbf{F} \\
\mathbf{F} \\
\mathbf{F}\end{array}$ & $\begin{array}{r}41 \\
130 \\
22 \\
54\end{array}$ & $\begin{array}{c}\text { counted } \\
<1 \\
<1 \\
2 \\
<1\end{array}$ & $\begin{array}{l}\text { ", } \\
\text { ”, }\end{array}$ & $\begin{array}{r}41 \\
2 \\
16 \\
3\end{array}$ & $\begin{array}{l}10^{6+} \\
10^{2-3} \\
10^{4-5} \\
\text { Not }\end{array}$ & $\begin{array}{l}48 \text { hours } \\
<2 \text { "' } \\
<2 \text { "” } \\
2 \text { weeks }\end{array}$ \\
\hline $\begin{array}{l}\mathbf{F} \\
\mathbf{F} \\
\mathbf{F} \\
\mathbf{F} \\
\mathbf{F} \\
\mathbf{F} \\
\mathbf{F} \\
\mathbf{F} \\
\mathbf{F} \\
\mathbf{M} \\
\mathbf{F}\end{array}$ & $\begin{array}{r}92 \\
54 \\
190 \\
38 \\
126 \\
37 \\
73 \\
52 \\
37 \\
51 \\
26\end{array}$ & $\begin{aligned}<1 \\
<1 \\
<1 \\
<1 \\
<1 \\
<1 \\
<1 \\
<1 \\
<1 \\
<\begin{array}{l}2 \\
21\end{array}\end{aligned}$ & $\begin{array}{l}\text { ”, } \\
\text { ”, } \\
\text { ”, } \\
\text { ”, } \\
\text { ”, } \\
\text { ”, }\end{array}$ & $\begin{array}{r}92 \\
54 \\
17 \\
38 \\
126 \\
37 \\
73 \\
35 \\
15 \\
51 \\
17 \\
12\end{array}$ & $\begin{array}{l}\text { counted } \\
10^{6+} \\
10^{6+} \\
10^{4} \\
10^{5-6} \\
10^{6} \\
10^{6} \\
10^{8} \\
10^{5-6} \\
10^{4-5} \\
10^{4-5} \\
10^{5-6} \\
10^{5-6}\end{array}$ & 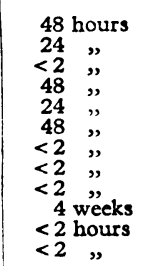 \\
\hline
\end{tabular}

these by the aspiration of sterile bladder urine. Infection was probably absent in a further five on the basis of subsequent negative clean-bag specimens, and continued well-being. Further urine specimens could not be obtained from five of the 33 babies, who were nevertheless clinically well when last seen, and from one baby who was inadvertently treated on the basis of the first urine report. It seems likely that the incidence of true infection in this series has been nil.

Specimens Obtained by Suprapubic Aspiration.-Twentyfive specimens were obtained from 22 babies. All specimens were shown to be sterile. Cell counts ranged from $<1$ to $6 / \mathrm{cu}$. mm. In the Table we compare the results of cell and bacterial counts on aspirated specimens with the results obtained by clean-bag collection in the same infant, usually on the same day and often within an hour.

\section{Results in Second Series}

Nineteen children have been investigated so far. The advantages of the procedure are already clear, as the following case reports illustrate.

\section{Ailing Neonate}

A baby girl aged 11 days was reported not to be gaining weight, to be sleepy, and to have vomited on several occasions. There were no abnormal signs apart from a mild pyrexia. A clean-bag specimen of urine contained 490 white cells/cu. mm. with a moderate growth of Escherichia coli and other organisms. The next day simultaneous clean-bag and suprapubic specimens were collected. While the clean-bag specimen again contained an excess of white cells (155/ cu. $\mathrm{mm}$.) the suprapubic aspiration specimen was sterile and cellfree. More frequent feeds were given and the infant thrived. It is likely that the cells came from vaginal secretions and vaginal reflux, which is common during micturition in the supine position (Elstein, 1963 ; Davis and Chumley, 1966).

There have been five similar instances so far of neonates with various symptoms who have escaped unnecessary treatment and investigations for a nonexistent infection of the urinary tract.

\section{Diagnosis or Exclusion of Infection of the Urinary Tract in the presence of Vulvovaginitis, Urethritis, or Balanoposthitis}

These conditions make satisfactory preparation impossible, and contraindicate catheterization of the bladder from below.

An 11-month-old girl developed restlessness, fever, and anorexia. She had an extensive napkin rash. Infection of the urinary tract was thought likely in the absence of any physical signs, and a standard specimen obtained with maximum precautions contained 10 white cells per high-power field and grew profuse $E$. coli. Shortly before treatment was due to begin on the following day a suprapubic aspiration showed that there were no organisms in the bladder urine. Her symptoms continued and she developed a respiratory infection.

A 16-month-old girl was referred because of vulval discharge. Examination showed a reddened vulva with mucopurulent exudate. Clean-bag urine contained numerous (more than $500 / \mathrm{cu} . \mathrm{mm}$.) pus cells and grew profuse $E$. coli. The interpretation of this result was difficult because of the state of the vulva. Suprapubic urine also yielded a heavy growth of $E$. coli and numerous pus cells, and a diagnosis of urinary infection in addition to vulvovaginitis could be made. $\beta$-haemolytic streptococci (Lancefield group $G$ ) were grown from the vulval exudate.

A 2-year-old boy had a history of recent onset of frequency, with a little urethral discharge. Suprapubic aspiration showed no evidence of infection in the bladder urine. The cause of the urethritis could not be determined.

\section{Infection without Pyuria}

An 18-month-old girl presented with 10 days' dysuria and frequency. A clean-bag specimen contained less than one white cell/cu. mm., but there was a profuse growth of Proteus mirabilis. 
A further clean-bag specimen a week later contained 4 white cells/ cu. mm. with a scanty mixed growth of organisms. Symptoms had largely subsided without treatment, but a suprapubic aspiration specimen taken immediately before the second clean-bag specimen contained less than one white cell/cu. mm., with $10^{4-5} P$. mirabilis per $\mathrm{ml}$. She was therefore regarded as having a true infection of the urinary tract and treated accordingly.

\section{Differential Diagnosis of Haematuria}

A 2-year-old girl was seen after she had passed several specimens of "brown" urine. She was afebrile and had minimal symptoms. Tests for blood were positive. Suprapubic aspiration provided immediate and unequivocal evidence of infection, which could be effectively treated at once.

\section{Discussion}

Paediatricians and pathologists are all too familiar with the practical difficulties of making a diagnosis of infection of the urinary tract. In clinical laboratory practice contaminated infant specimens are the rule rather than the exception, since one seldom receives catheter, midstream, or carefully collected clean-voided specimens from these patients. Interpretation of the results remains uncertain; this is why the clinician may disregard them when they fail to conform to his concept of a particular case.

In some laboratories the degree of pessimism is such that only infant specimens showing pyuria are actually cultured. This practice may account for the reluctance of some clinicians to recognize that infection may occur without pyuria, and that a "positive" culture in the presence of white cells does not necessarily mean infection of the bladder urine.

This unsatisfactory state of affairs leads to unnecessary laboratory work and uncertain diagnoses. Our experience with the use of suprapubic aspiration is still limited but has already enabled us to overcome the problem of interpretation of doubtful results whenever we have used the method. Laboratory reports have become decisive.

The source of the white cells and organisms that may contaminate even the most carefully collected standard specimen is probably the vagina or the recesses under a non-retractile foreskin. Vaginal reflux is often noted radiologically when an infant empties her bladder during micturition cystography in the supine position (Davis and Chumley, 1966), and white cells appear in the vaginal secretions after the third to fourth day of life (Elstein, 1963). Lincoln and Winberg (1964) showed that irrigation and gentle massage followed by further cleansing of the prepuce reduced the bacterial contamination of urine specimens, but this is not a technique that lends itself to general use.

It is clear from our results that the diagnosis of urine infection in the newborn cannot be safely based on the findings in clean-bag specimens. In acute illness where diagnosis is urgent we believe with Pryles (1960) that urine specimens should be collected under personal, not delegated, supervision. Collection should be preceded by very thorough cleansing and a true midstream catch obtained. Female infants should be held sitting erect to minimize vaginal reflux. If this procedure is impracticable or the results are indecisive, urine should be aspirated from the bladder through the anterior abdominal wall, with the guarantee that contamination can be avoided and that the result will be diagnostic. In less urgent cases we continue to use standard methods supplemented by suprapubic aspiration were necessary. Suprapubic aspiration of urine can be done as an outpatient procedure. The trauma is of the order of an intramuscular injection, and the required skill is no greater. Impatience must be restrained, for if there is no impairment of percussion note over the bladder, failure to obtain urine may follow.

After over 50 suprapubic aspirations in newborn infants and young children we have not encountered any side-effects other than microscopical haematuria of short duration. A technical failure (the incidence in our hands is of the order of $10 \%$ ) should be followed by a further attempt one or two hours later. Contamination with skin organisms can be entirely avoided by careful technique.

\section{Summary}

White cell and bacterial counts were performed on routinely collected urine specimens from 162 thriving neonates. White cell counts of $20 / \mathrm{cu}$. mm. or more were found in $20 \%$ of babies ( $48 \%$ of the girls, $2 \%$ of the boys). Bacterial counts in excess of $10^{5} / \mathrm{ml}$. were found in $64 \%$ of both the girls and the boys. Follow-up indicated that none of the infants were infected. Suprapubic needle aspiration of the bladder was performed in 22 of the infants with "abnormal" urines and yielded sterile urine. It is therefore necessary to revise the criteria for the diagnosis of infection of the urinary tract in the neonate.

The value of suprapubic aspiration of urine in sick infants is demonstrated. The method is recommended whenever contamination appears to be unavoidable or where standard techniques have given ambiguous results.

\section{Appendix}

Suprapubic Aspiration of Urine (after Pryles, 1965).-A disposable plastic syringe, a No. 21 gauge $1 \frac{1}{2}$-in. $(3.8 \mathrm{~cm}$.) needle, sterile swabs, and suitable antiseptic solution are prepared. We prefer $0.5 \%$ chlorhexidine in $70 \%$ spirit, or tincture of iodine. The napkin is removed only when everything is ready, and an assistant steadies the legs and is prepared to compress the urethra by squeezing the labia or the penile urethra at the first sign of voiding. The bladder is percussed ; occasionally it is deviated to the right by the colon. If there is only very slight impairment of percussion note, the napkin should be replaced and nothing more done for an hour. When a suitably impaired percussion note has been found, irrespective of whether the napkin is wet or dry, the skin is sterilized and the bladder entered with a stabbing movement in the midline, about 2 to $2.5 \mathrm{~cm}$. above the pubis, holding the syringe vertically with the baby lying supine. The needle may be felt to enter the bladder almost immediately, or not until it has been inserted for an inch $(2.5 \mathrm{~cm}$.) or more. This is probably because a partly full bladder can yield in front of the needle. Urine is aspirated and the needle withdrawn. The needle is now discarded and the syringe sealed with a sterile cap or second needle. The specimen is sent to the laboratory in the sealed syringe. The parent is instructed to report any haematuria, but this has not so far occurred in our experience. Microscopical haematuria is often found in specimens collected shortly after bladder puncture.

We would like to thank Dr. B. D. R. Wilson, Dr. D. G. Cottom, Dr. U. James, Mr. R. B. K. Rickford, Professor P. Rhodes, and the late Mr. G. W. Garland for permission to examine the neonates under their care. We are also indebted to Dr. Charles Brook, Miss R. M. Harris, and the midwives in the neonatal nurseries who spent much time and trouble in collecting the specimens, and to Dr. M. Ridley for his advice and the provision of laboratory facilities.

\section{REFERENCES}

Beard, R. W., McCoy, D. R., Newton, J. R., and Clayton, S. G. (1965). Lancet, 2, 610 .

Davis, L. A., and Chumley, W. F. (1966). Pediatrics, 38, 293.

Elstein, M. (1963). 7. Obstet. Gynaec. Brit. Cwlth, 70, 1050.

Hodson, C. J., and Wilson, S. (1965). Brit. med. J., 2, 191.

James, U. (1959). Lancet, 2, 1001.

Lincoln, K., and Winberg, J. (1964). Acta paediat. (Uppsala), 53, 307.

Lloyd Still, J., and Cottom, D. G. (1967). Arch. Dis. Childh., 42, 34.

Nelson, J. D., and Peters, P. C. (1965). Pediatrics, 36, 132.

Atkin, M. D., Morse, T. S., and Welch, K. J. (1959). Ibid., 24, 983.

Pryles, C. V. (1960). Ibid., 26, 441.

Pryles, C. V. (1960). Ibid.,

Smellie, J. M., Hodson, C. J., Edwards, D., and Normand, I. C. S. (1964). Brit. med. Ұ., 2, 1222 .

Stamey, T. A., Govan, D. E., and Palmer, J. M. (1965). Medicine (Baltimore), 44, 1 .

Stansfeld, J. M. (1966). Brit. med. F., 1, 631 